\title{
MODEL PENGEMBANGAN KARAKTER MELALUI SISTEM PENDIDIKAN TERPADU INSANTAMA BOGOR
}

\author{
Agus Retnanto \\ STAIN KUDUS, Jawa Tengah, Indonesia \\ agus_retnanto@yahoo.co.id
}

\begin{abstract}
Abstrak
Penelitian ini bertujuan untuk mengetahui secara mendalam tentang bagaimana model pengembangan karakter siswa pada Pendidikan Terpadu Insantama Bogor. Kajian ini menggunakan pendekatan kualitatif yaitu mengkaji perilaku manusia dalam setting alamiah dengan fokus interpretasi budaya terhadap perilaku siswa. Nilai kegunaan atau urgensi dari penelitian ini diharapkan mempunyai implikasi untuk membantu menyumbangkan pemikiran yang berkaitan dengan pendidikan, dalam rangka pencapaian tujuan Pendidikan Nasional dalam Sistem Pendidikan Nasional sehingga dapat menambah khasanah ilmu pendidikan khususnya dalam rangka membentuk manusia Indonesia seutuhnya. Membantu memberikan sebuah konsep sistem pendidikan yang dapat digunakan untuk menciptakan manusia cerdas sekaligus berakhlaq mulia yang mampu mengatasi berbagai macam problem yang sedang melanda manusia Indonesia yang sedang membangun.
\end{abstract}

Kata Kunci: model, karakter, pendidikan ,terpadu.

\begin{abstract}
CHARACTER DEVELOPMENT MODEL THROUGH INTEGRATED EDUCATION SYSTEM OF INSANTAMA BOGOR. This study aims to learn in depth about how the character development model works in students of the Integrated Education Insantama Bogor. This study uses qualitative approach which examines human behavior
\end{abstract}


in a natural setting with a focus on cultural interpretation to such behavior. The urgency of this research is expected to have implications for helping contribute ideas related to education, in order to achieve the National Education Goals in the national education system so as to increase the repertoire of science education, especially in order to form a good Indonesian. This study tries to provide an education system concept that can be used to create a smart man and have a good character which is able to a wide range of human problems that hit Indonesian.

Keywords: character, model, education system

\section{A. Pendahuluan}

Tujuan pendidikan merupakan gambaran dari falsafah atau pandangan hidup manusia, baik secara perseorangan maupun kelompok. Membicarakan tujuan pendidikan akan menyangkut sistem nilai dan norma-norma dalam suatu konteks kebudayaan, baik dalam mitos, kepercayaan, religi, filsafat, ideologi dan sebagainya. Oleh karena pendidikan merupakan suatu proses sengaja dari suatu generasi kepada anak didik sebagai generasi penerus yang lebih baik, maka tujuan pendidikan diarahkan oleh perseorangan atau kelompok suatu generasi pada core value yang telah dipikirkan atau disepakati bersama.

Dunia pendidikan menyimpan kompleksitas masalah yang sangat luas, dari masalah dasar filosofis, gagasan, visi, misi, institusi, program, manajemen, SDM, kependidikan, kurikulum, sarana prasarana, teknologi kependidikan, lingkungan pendidikan, pembiayaan, partisipasi masyarakat, kualitas output pendidikan serta relevansinya dengan dinamika masyarakat dan tuntutan sosio kultural sekitarnya. Oleh karena itu, dibutuhkan adanya gagasan segar dan kreatif serta upaya dinamis untuk menyelenggarakan modelmodel pendidikan Islam yang excellent, bermartabat, dan menjadi kebanggaan umat serta mampu memberikan jawaban terhadap kebutuhan pendidikan yang dapat melakukan fungsi penyelamatan fitrah sekaligus pengembangan potensi-potensi fitrah manusiawi secara padu dan berimbang.

Pendidikan di Indonesia diharapkan bersifat humanis-relegius dimana dalam pengembangan kehidupan (ilmu pengetahuan) tidak terlepas dari nilai keagamaan dan kebudayaan. Nilai keagamaan dan 
kebudayaan merupakan nilai inti bagi masyarakat yang dipandang sebagai dasar untuk mewujudkan cita-cita kehidupan yang bersatu, bertoleransi, berkeadilan, dan sejahtera. Nilai keagamaan bukan dipandang sebagai nilai ritual yang sekedar digunakan untuk menjalankan upacara keagamaan dan tradisi, tetapi diharapkan menjadi bagian yang tidak terpisahkan dari kegiatan kehidupan untuk memenuhi kebutuhan kesejahteraan sosial, intelektual, harga diri, dan aktualisasi diri.

Masalah-masalah sosial seperti kemiskinan, kebodohan, pengangguran, kejahatan, dan lain-lain, adalah merupakan keadaan yang tidak sesuai dengan nilai-nilai keagamaan dan kemanusiaan. Oleh karenanya pemecahan masalah sosial tersebut harus menggunakan nilai keagamaan dan kemanusiaan sebagai dasar kearifan untuk mencari cara pemecahannya, disamping cara yang bersifat ilmiah pragmatis (Kuntoro, 2008: 11). Kehidupan yang didominasi oleh pemenuhan kebutuhan material akan mendorong kehidupan yang penuh dengan konflik, ketidakadilan, kesenjangan sosial yang menghancurkan, dan menjauhkan dari hubungan persaudaraan yang harmonis, dan persamaan. Manusia menjadi dihinggapi dengan karakter kepemilikan (having character) yang membahayakan orang lain juga diri-sendiri. Having character tidak terbatas pada kepuasan menguasai benda material sebagai objek pemuasan, tetapi meluas pada penguasaan atas manusia lain dan alam sebagai bagian dari objek pemuasan (Erich Fromm dalam Kuntoro, 2008: 14).

Kehidupan yang penuh persaingan dan konflik antar umat manusia lebih dipicu oleh karakter dan sikap pemilikan material yang berlebihan. Pendidikan yang selama ini berkembang lebih menekankan pada penguasaan ilmu pengetahuan dan teknologi yang kurang disertai dasar yang kuat pada pengembangan karakter manusia yang memiliki hati nurani mulia. Pengembangan sumberdaya manusia sebagai instrumen bagi perolehan kemajuan ekonomi dan persaingan lebih menonjol daripada pengembangan karakter atau akhlak manusia. Pendidikan keagamaan merupakan substansi penting bagi pendidikan di sekolah atau dalam kehidupan sosial agar pendidikan memiliki karakter humanis-relegius.

Masyarakat saat ini tengah menghadapi krisis multidimensional dalam segala aspek kehidupan. Kemiskinan, kebodohan, kedzaliman, 
penindasan, ketidakadilan di segala bidang, kemerosotan moral, peningkatan tindak kriminal dan berbagai bentuk penyakit sosial menjadi bagian tak terpisahkan dari kehidupan masyarakat. Mengapa semua ini terjadi? Dalam keyakinan Islam, krisis multidimensi tadi merupakan kerusakan ( fasad) yang ditimbulkan oleh kemaksiatan yang dilakukan manusia setelah sekian lama hidup dalam sistem sekuleristik. Yakni tatanan ekonomi yang kapitalistik, perilaku politik yang oportunistik, budaya hedonistik, kehidupan sosial yang egoistik dan individualistik, sikap beragama yang sinkretistik serta paradigma pendidikan yang materialistik.

Satu-satunya cara yang harus dilakukan untuk keluar dari krisis pendidikan itu adalah mengembalikan proses pendidikan kepada konsepsi pendidikan Islam yang benar. Secara paradigmatis, aqidah Islam harus dijadikan sebagai penentu arah dan tujuan pendidikan, penyusunan kurikulum dan standar nilai ilmu pengetahuan serta proses belajar mengajar, termasuk penentuan kualifikasi guru serta budaya sekolah yang akan dikembangkan. Paradigma baru yang berasaskan pada aqidah Islam ini harus berlangsung secara berkesinambungan pada seluruh jenjang pendidikan yang ada, mulai dari Taman Kanak-kanak (TK) hingga Perguruan Tinggi.

Berangkat dari paparan di atas, Pendekatan dan model penelitian yang digunakan dalam penelitian ini adalah pendekatan kualitatif model Spreadley. Analisis tersebut terdiri atas empat langkah, yaitu analisis domein, analisis taksonomi, analisis komponen, dan analisis tema. Analisis domein dimaksudkan untuk menentukan domein budaya yang berisi kategori-kategori yang lebih kecil yang meliputi istilah bagian, istilah acuan, dan hubungan semantik antara istilah bagian dan istilah acuan itu. Analisis taksonomi dimaksudkan untuk mengorganisasikan domein-domein beserta bagian-bagiannya itu sehingga terbentuk suatu konstelasi yang utuh. Analisis komponen dimaksudkan untuk mencari atribut-atribut unsur dalam setiap domein guna mengidentifikasi kontras diantara unsurunsur dalam domein tersebut, sehingga masing-masing domein dapat diidentifikasikan secara jelas dan dapat dilihat kontrasnya dengan domein-domein lainnya. Analisis tema dimaksudkan untuk menentukan hubungan antar domein dan hubungan antara domeindomein tersebut dengan pemandangan budaya secara keseluruhan 
(Spraedley, 1980: 87-88).

Sesuai dengan sumber datanya, teknik pengambilan data meliputi pengamatan (untuk sumber data peristiwa), wawancara (untuk sumber data responden), dan analisis dokumen (untuk sumber data dokumen). Dari ketiga sumber yang dapat memberikan data tersebut, peneliti membidik peristiwa seperti kegiatan belajar mengajar baik di dalam ruang maupun di luar kelas. Respoden, baik kepala sekolah, guru, siswa, orangtua siswa maupun masyarakat sekitar lembaga pendidikan. Dokumen, berupa segala bentuk informasi tertulis, seperti kurikulum, buku-buku administrasi lain yang mendukung proses pembelajaran. Peneliti juga memakai teknik snowball sampling dengan maksud tidak hanya mendatangi satu orang yang dipandang memiliki informasi yang dibutuhkan, namun pada tahap selanjutnya akan mendatangi orang lain atas rekomendasi orang yang sebelumnya ditemuinya. Pencarian data dapat dihentikan manakala peneliti menganggap bahwa informasi telah jenuh.

\section{B. Pembahasan}

\section{Pengertian Pendidikan Karakter}

Pendidikan Dalam arti sederhana sering diartikan sebagai usaha manusia untuk membina kepribadiannya sesuai dengan nilainilai di dalam masyarakat dan kebudayaan. Dalam perkembangannya, istilah pendidikan atau paedagogie berarti bimbingan atau pertolongan yang diberikan dengan sengaja oleh orang dewasa agar ia menjadi dewasa. Selanjutnya, pendidikan diartikan sebagai usaha yang dijalankan oleh seseorang atau kelompok orang lain agar menjadi dewasa atau mencapai tingkat hidup atau penghidupan yang lebih tinggi dalam arti mental.

Selanjutnya Menurut UU Nomor 2 Tahun 1989 pendidikan adalah usaha sadar untuk menyiapkan peserta didik melalui kegiatan bimbingan, pengajaran, dan atau latihan bagi peranannya di masa yang akan datang. Perkembangan berikutnya menurut UU No. 20 tahun 2003 pendidikan adalah usaha sadar dan terencana untuk mewujudkan suasana belajar dan proses pembelajaran agar peserta didik secara aktif mengembangkan potensi dirinya untuk memiliki kekuatan spiritual keagamaan, pengendalian diri, kepribadian, kecer- 
dasan, akhlak mulia, serta keterampilan yang diperlukan dirinya, masyarakat, bangsa, dan negara.

Beberapa pengertian atau batasan pendidikan redaksional namun secara essensial terdapat kesatuan unsur-unsur atau faktorfaktor yang terdapat di dalamnya, yaitu bahwa pengertian pendidikan tersebut menunjukkan suatu proses bimbingan, tuntunan atau pimpinan yang didalamnya mengandung unsur-unsur seperti pendidik, anak didik, tujuan dan sebagainya. Karena itu, dengan memperhatikan batasan-batasan pendidikan tersebut, ada beberapa pengertian dasar yang perlu dipahami sebagai berikut.

Pendidikan karakter adalah sebuah upaya membimbing perilaku manusia menuju standar-standar baku. Upaya ini juga memberi jalan untuk menghargai persepsi dan nilai-nilai pribadi yang ditampilkan di sekolah. Fokus pendidikan karakter adalah pada tujuan-tujuan etika, tetapi praktiknya meliputi penguatan kecakapankecakapan yang penting yang mencakup perkembangan sosial peserta didik.

Pendidikan nilai atau pendidikan karakter harus bermuatan pengalaman dan pengamalan, yang melibatkan unsur inti manusia, yaitu hati dan budi serta seluruh anggota tubuhnya (Adimasana, 2000: 35-36). Nilai-nilai yang dijadikan acuan dalam pendidikan nilai adalah nilai-nilai yang berharga untuk membangun kehidupan. Masyarakat, negara, agama dan keluarga mengarahkan perhatian pada nilai-nilai yang penting untuk hidup, yang menjadi dasar untuk hidup bersama dan yang memperkaya manusia melalui norma-norma. Norma-norma adalah wahana atau pedoman untuk mewujudkan nilai-nilai. Jika seseorang melaksanakan suatu norma dengan sungguh-sungguh; kemudian ia merasakan dan menyadari nilainya, maka ia akan dapat menghayati nilai yang terkandung di dalamnya.

Manusia hidup digerakkan oleh nilai-nilai. la harus memilih apakah mengambil nilai-nilai yang baik atau yang buruk, atau samasama balk atau nilai yang baik dan nilai yang lebih baik, bahkan terbaik. Dalam mempertimbangkan berbagai nilai yang dihadapi, manusia harus memutuskan nilai mana yang akan diambil untuk dasar tindakannya. Harapan semua orang tua dan pendidik tentunya adalah keputusan tersebut sesuai dengan nilai-nilai luhur yang 
meninggikan harkat dan martabat manusiawinya sehingga sisi kemanusiaan mengejawantah dalam perilaku dan perbuatannya.

Max Scheler mengungkapkan bahwa nilai moral "membonceng" pada nilai-nilai lain (Bertens, 1993: 147). Artinya, nilai moral mengikuti ke mana pun seseorang pergi dan apa yang dilakukannya. Maka, pendidikan nilai sesungguhnya dapat terlaksana melalui segala macam kegiatan yang memenuhi seluruh ruang dan waktu dalam hidup seseorang di mana saja, dan sudah tentu di sekolah. Di sekolah peserta didik sebagai manusia menangkap nilainilai, meresapi, mentransformasikan dan merealisasikannya dalam kehidupan.

Menumbuhkembangkan nilai-nilai insani dan Ilahi di sekolah merupakan upaya terus-menerus yang memerlukan dukungan dari orang tua untuk sama-sama menciptakan lingkungan belajar nilai yang.seiring sejalan. Artinya, nilai-nilai yang diperkenalkan dan diinternalisasikan di sekolah sama dengan yang diinternalisasikan di rumah. Hal-hal yang dilarang di sekolah juga dilarang di rumah. Hal-hal yang harus dilakukan oleh subjek didik di sekolah juga harus dilakukan di sekolah sehingga kecil kesempatan anak untuk bermain peran atau menggunakan standar ganda, yaitu di sekolah bersikap patuh dan disiplin pada norma-norma, tetapi di rumah justru sebaliknya. Dapat dikatakan bahwa hal-hal yang ada di sekeliling anak baik yang dekat maupun yang jauh, langsung maupun tidak langsung berpengaruh terhadap pembentukan kepribadian seorang anak sampai la dewasa kelak, bahkan selama hidupnya. Dengan upaya terus-menerus dari orang tua dan sekolah dalam pendidikan nilai diharapkan anak sebagai subjek didik memiliki karakter yang baik.

\section{Sejarah Pendidikan Terpadu Insantama Bogor}

\section{a. Konsep Dasar Penyelenggaraan Pendidikan Terpadu}

Pendidikan dalam pandangan Islam harus merupakan upaya sadar dan terstruktur serta sistematis untuk mensukseskan misi penciptaan manusia sebagai abdullah dan khalifah Allah di muka bumi sebagaimana telah diuraikan di muka. Upaya pendidikan seperti ini harus merupakan bagian yang tak terpisahkan dari sistem hidup Islam. Sebagai bagian integral dari sistem kehidupan Islam, sistem pendidikan memperoleh masukan dari supra sistem, yakni 
keluarga dan masyarakat atau lingkungan, dan memberikan hasil/ keluaran bagi suprasistem tersebut. Sementara sub-subsistem yang membentuk sistem pendidikan antara lain adalah tujuan pendidikan itu sendiri, anak didik (pelajar/mahasiswa), manajemen, struktur dan jadwal waktu, materi, tenaga pendidik/pengajar dan pelaksana, alat bantu belajar, teknologi, fasilitas, kendali mutu, penelitian dan biaya pendidikan.

Proses pendidikan dapat terjadi dimana saja, sehingga berdasarkan pengorganisasian serta struktur dan tempat terjadinya proses tersebut, dikenai adanya pendidikan sekolah dan pendidikan luar sekolah. Melalui proses ini diperoleh hasil pendidikan yang mengacu pada tujuan pendidikan yang telah ditentukan. Bagi pendidikan sekolah maka tujuan pendidikannya ditetapkan berdasarkan tingkat kebutuhan dan tetap bermuara pada tujuan pendidikan Islam.

Selanjutnya, hasil pendidikan ini dikembalikan kepada supra sistem atau lingkungan. Di dalam lingkungan inilah, hasil pendidikan akan menjadi indikator efektivitas dan efisiensi proses pendidikan dalam sistem pendidikan. Dari hasil pendidikan, sistem pendidikan beroleh umpan balik yang dapat digunakan untuk memperbaiki dan meningkatkan mutu proses pendidikan.

Dari gambaran pendidikan secara sistemik di atas diketahui bahwa terdapatnya kesinambungan tujuan pendidikan dalam setiap jenjang pendidikan sekolah (formal) adalah semata-mata didasarkan atas kemampuan anak didik sebagai subsistem masukan dalam menjalani proses pendidikan. Untuk menjaga kesinambungan proses pendidikan dalam menjabarkan pencapaian tujuan pendidikan itu maka keberadaan kurikulum pendidikan menjadi suatu kebutuhan yang tidak terejakkan. Kurikulum pendidikan Islam sangatlah khas, unique, Kurikulum ini memiliki ciri-ciri yang sangat menonjol pada tujuan/arah pendidikannya, unsur-unsur pelaksana pendidikannya serta pada asas dan struktur kurikulumnya.

b. Visi, Misi dan Tujuan Pendidikan Islam Terpadu Insantama Bogor

1) Sekolah Dasar Islam Terpadu Insantama

Visi dari SDIT Insantama ialah mewujudkan SDIT Insantama 
sebagai lembaga pendidikan yang bermutu tinggi dan unggul di Indonesia. Sedangkan misinya yaitu menyelenggarakan pendidikan dasar berlandaskan Islam yang memadukan aspek pembentukan kepribadian Islam, dasar-dasar penguasaan tsaqofah Islam dan sains teknologi, dalam suasana budaya pendidikan yang religius serta didukung oleh peran serta orang tua dan masyarakat. SDIT Insantama memiliki tujuan sebagai berikut: (1) Mendidik anak muslim sehingga menjadi manusia yang cerdas, aktif-kreatif dan berkepribadian Islam, (2) Mewujudkan sebuah institusi pendidikan dasar secara terpadu, (3) Menciptakan lingkungan pendidikan integratif antara aspek afektif, kognitif dan psikomotorik dalam suasana pendidikan Islami, (4) Menggalang peran serta masyarakat dalam pembinaan anakanak.

2) Sekolah Menengah Pertama Islam Terpadu Insantama

Visi dari SMPIT Insantama adalah mewujudkan SMPIT Insantama sebagai lembaga pendidikan yang bermutu tinggi dan unggul di Indonesia. Misi dari SMPIT Insantama ialah menyelenggarakan pendidikan dasar berlandasakan Islam yang memadukan aspek pembentukan kepribadian Islam, dasar-dasar penguasaan tsaqofah Islam dan sains teknologi, dalam suasana budaya pendidikan yang religius serta didukung oleh peran serta orang tua dan masyarakat. Sedangkan tujuannya yaitu (1) Mendidik anak muslim sehingga menjadi manusia yang cerdas, aktif-kreatif dan berkepribadian Islam, (2) Mewujudkan sebuah institusi pendidikan dasar secara terpadu, (3) Menciptakan lingkungan pendidikan integratif antara aspek afektif, kognitif dan psikomotorik dalam suasana pendidikan Islami, (4) Menggalang peran serta masyarakat dalam pembinaan anak-anak.

3) Sekolah Menengah Atas Islam Terpadu Insantama

Visinya ialah mewujudkan SMAIT Insantama sebagai lembaga pendidikan yang bermutu tinggi dan unggul di Indonesia. Misinya yaitu menyelenggarakan pendidikan menengah atas berlandaskan Islam yang memadukan aspek pemantapan kepribadian Islam, penguasaan tsaqofah Islam dan sains teknologi untuk melanjutkan ke jenjang pendidikan tinggi, dalam suasana budaya pendidikan berpesantren serta didukung oleh peran serta orang tua dan masyarakat. Tujuan SMAIT Insantama adalah (1) Terwujudnya 
siswa pemimpin masa depan yang mantap dalam kepribadian Islam, penguasaan tsaqofah Islam dan sains teknologi hingga dapat diterima di perguruan tinggi terkemuka di dalam dan luar negeri. (2) Terwujudnya lembaga pendidikan menengah atas Islam terpadu yang bermutu tinggi dan unggul di Indonesia

\section{c. Tujuan Pendidikan Terpadu Insantama Bogor}

Tujuan pendidikan adalah suatu kondisi yang menjadi target penyampaian ilmu pengetahuan. Tujuan ini juga merupakan panduan dan acuan bagi seluruh kegiatan dalam sistem pendidikan. Matra, sebagaimana pengertiannya, Pendidikan Islam merupakan upaya sadar, terstruktur, terprogram dan sistematis bertujuan untuk membentuk manusia yang berkarakter, yakni (1) berkepribadian Islam, (2) menguasai tsaqofah Islam, (3) menguasai ilmu kehidupan (iptek) dan (4) memiliki ilmu kehidupan (keterampilan) memadai.

\section{d. Memiliki Ilmu Kehidupan (Keahlian/Keterampilan) Memadai}

Perhatian besar Islam pada ilmu-ilmu teknik dan praktis serta latihan-latihan keterampilan dan keahlian, menempatkannya sebagai salah satu tujuan pendidikan Islam. Penguasaan keterampilan yang serba material ini juga merupakan tuntutan yang harus dilakukan oleh umat ini diindikasikan dengan terdapatnya banyak nash dalam Al-Qur'an dan yang mengisyaratkan kebolehan mempelajari ilmuilmu pengetahuan umum atau keterampilan (seperti yang beberapa di antaranya telah diungkapkan sebelumnya). Sebagaimana halnya dengan iptek, Islam juga menjaclikan penguasaan keterampilan sebagai fardlu kifayah, yaitu suatu kewajiban yang harus dikerjakan oleh sebagian rakyat apabila ilmu-ilmu tersebut sangat dibutuhkan umat, seperti rekayasa industri, penerbangan, pertukangan dan lainnya.

\section{e. Unsur Pelaksana Pendidikan Terpadu Insantama Bogor}

Berdasarkan pengorganisasian, proses pendidikan bisa dibagi menjadi doa, yakni secara formal di sekolah/kampus dan secara nonformal di luar kampus sekolah/lingkungan, yakni keluarga dan masyarakat.

Pendidikan di sekolah Terpadu Insantama Bogor pada dasarnya merupakan proses pendidikan yang diorganisasikan secara formal berdasarkan struktur Herarkhis dan kronologis, dari jenjang 
taman kanak-kanak hingga perguruan tinggi. Selain mengacu pada tujuan pendidikan yang diterapkan secara berjenjang, berlangsungnya proses pendidikan di sekolah/kampus sangat bergantung pada keberadaan subsistem-subsistem lain yang terdiri atas: anak didik (pelajar/mahasiswa); manajemen penyelenggaraan sekolah/ kampus; struktur dan jadwal waktu kegiatan belajar-mengajar; materi bahan pengajaran yang diatur dalam seperangkat sistem yang disebut sebagai kurikulum; tenaga pendidik/pengajar dan pelaksana yang bertanggung jawab atas terselenggaranya kegiatan pendidikan; alai bantu belajar (buku teks, papan tulis, laboratorium, dan audiovisual); teknologi yang terdiri dari perangkat lunak (strategi dan taktik pengajaran) serta perangkat keras (peralatan pendidikan); fasilitas atau kampus beserta perlengkapannya; kendali mutu yang bersumber atas target pencapaian tujuan; penel'ifian untuk pengembangan kegiatan pendidikan, dan biaya pendidikan guna melancarkan kelangsungan proses pendidikan.

Berlangsungnya pendidikan di sekolah Dasar Islam Terpadu Insantama Bogor, berdasarkan sirah Rasul hingga masa tarikh Daulah Khilafah, dapat dideskripsikan sebagai berikut:

1) Kurikulum pendidikan didasarkan pada Aqidah Islam.

2) Mata pelajaran dan metodologi pendidikan untuk penyampaian pelajaran seluruhnya disusun sejalan dengan asas Aqidah Islam.

3) Tujuan penyelenggaraan pendidikannya merupakan penjabaran dari tujuan pendidikan Islam yang disesuaikan dengan tingkatan pendidikannya.

4) Sejalan dengan tujuan pendidikannya, waktu belajar untuk ilmu-ilmu Islam (Tsaqofah Islamiyyah) diberikan setiap minggu dengan proporsi yang disesuaikan dengan waktu pelajaran ilmu-ilmu kehidupan (iptek dan keterampilan).

5) Pelajaran ilmu-ilmu terapan dan sejenisnya (iptek dan keterampilan) dipisahkan dengan pelajaran guna membentuk syakhsiyyah Islamiyah dan tsaqofah lslamiyyah. Khusus untuk materi guna membentuk syakhsiyyah Mamiyah mulai diberikan di tingkat dasar sebagai materi pengenalan dan kemudian meningkat pada materi pembentukan dan peningkatan setelah usia anak didik menginjak baligh (dewasa). Sementara materi 
tsaqofah lslamiyyah dan pelajaran ilmu-ilmu terapan dan sejenisnya diajarkan secara bertingkat dari mulai tingkat dasar.

6) Bahasa Arab menjadi bahasa pengantar di seluruh jenjang pendidikan, baik negeri maupun swasta.

7) Materi pelajaran yang bermuatan paham kufur, seperti ideologi sosialis/komunis atau liberal/kapitalis, aqidah ahli kitab dan lainnya juga ilmu-ilmu filsafat, ilmu sosial, sejarah asing, bahasa maupun sastra asing dan lainnya, hanya diberikan pada tingkat pendidikan tinggi yang tujuannya hanya untuk menjelaskan kebobrokan dan kesalahannya, bukan untuk diamalkan.

Libur sekolah hanya diberikan pada hari Raya idul Fitri dan Idul Adha (termasuk hari tasyriq). Masa pendidikan berlangsung sepanjang tahun dan tujuh hari dalam seminggunya. Hal ini menjadikan umat Islam biasa beretos kerja tinggi. Secara ringkas waktu belajar untuk setiap harinya dibagi menjadi dua kelompok: (1) jam pagi, dimulai jam 07.30 hingga waktu Dhuhur (jam 12.00) atau selama empat jam ditambah waktu istirahat; (2) jam sore, dimulai sejak selesainya shalat Ashar (jam 15.30) sampai dengan jam 20.00 atau setara dengan empat jam ditambah waktu istirahat.

\section{f. Pendidikan di tengah masyarakat}

Hampir sama dengan pendidikan di keluarga, pendidikan di tengah masyarakat pada hakikatnya juga merupakan proses pendidikan sepanjang hayat, khususnya berkenaan dengan praktek kehidupan seharihari yang dipengaruhi oleh sumber belajar yang ada di masyarakat, utamanya tetangga, teman pergaulan, lingkungan serta sistem nilai yang berjalan. Dalam sistem Islam, masyarakat adalah salah satu elemen penting penyangga tegaknya sistem selain rasa ketaqwaan yang tertanam dan terbina pada setiap individu serta keberadaan negara sebagai pelaksana syariat Islam.

Adanya sikap saling mengontrol pelaksanaan hukum Islam dan mengawasi serta mengoreksi tingkah laku penguasa pada masyarakat dimungkinkan mengingat masyarakat dalam perspektif Islam memiliki karakteristik tersendiri dalam membentuk perasaan taqwa dalam diri setiap individunya.

Karena itu, dengan sendirinya, proses pendidikan di tengah masyarakat ini menempati posisi penting. Masyarakat Islam 
Model Pengembangan Karakter Melalui Sistem Pendidikan Terpadu...

terbentuk dari individu-individu yang dipengaruhi oleh perasaan, pemikiran, dan peraturan yang mengikat mereka sehingga menjadi masyarakat yang solid persatuannya.

\section{g. Asas Pendidikan Terpadu Insantama Bogor}

Demikian pentingnya aqidah bagi kehidupan seorang muslim, maka Islam mengharuskan setiap muslim untuk memegang teguh aqidah itu dan menjadikannya dalam berfikir dan berbuat, termasuk ketika menyusun system pendidikan. Maka, kurikulum pendidikan yang dilaksanakan pun berlandaskan pada aqidah Islam. Karenanya, jika aqidah Islam telah menjadi asas yang mendasar bagi kehidupan seorang muslim, asas bagi hubungan antar sesama Muslim, asas bagi aturan dan masyarakat umumnya, dan asas bagi kehidupan bemegaranya, Maka seluruh pengetahuan yang diterima seorang muslim harus berdasarkan aqidah Islam pula. Seluruh pengetahuan tidak terkecuali, baik itu berupa pengetahuan yang berkaitan dengan kehidupan pribadi, hubungan sosial, masalah ekonomi, hukum, politik dan kenegaraan atau masalah apa pun yang berkaitan dengan kehidupan dunia dan akhirat, wajib berlandaskan pada aqidah Islam.

Namun begitu, penetapan aqidah Islam sebagai asas pendidikan tidaklah berarti bahwa setiap ilmu pengetahuan harus bersumber dari aqidah Islam. Islam tidak memerintahkan demikian. Lagi pula hal itu tidak sesuai dengan kenyataan, karena memang tidak semua ilmu pengetahuan terlahir dari aqidah Islam. Yang dimaksud dengan menjadikan aqidah Islam sebagai asas atau dasar dari ilmu pengetahuan adalah dengan menjadikan aqidah Islam dijadikan sebagai standar penilaian. Dengan istilah lain, aqidah Islam difungsikan sebagai kaidah atau tolak ukur pemikiran dan perbuatan.

\section{h. Struktur Kurikulum Pendidikan Terpadu Insantama Bogor}

Secara struktural, kurikulum pendidikan Islam di sekolah/ kampus dijabarkan dalam tiga komponen materi pendidikan utama yang sekaligus menjadi karakteristik khas, yakni: (1) Pembentukan Syakhsiyyah Islamiyyah (Kepribadian Islami), (2) Tsaqofah Islam dan (3) Ilmu Kehidupan (Iptek, keahlian dan Keterampilan).

Sebagaimana, yang tercermin dalam Label di bawah ini, selain muatan penunjang proses pembentukan Syakhshiyyah lslamiyyah 
yang secara menerus pemberiannya untuk tingkat TK - SD dan SMP - SMU - PT, muatan tsaqofah Islam dan Ilmu Kehidupan (Iptek, keahlian dan Keterampilan) diberikan secara bertingkat sesuai dengan daya serap dan tingkat kemampuan anak didik berdasarkan jenjang pendidikannya masing-masing.

1) Pembentukan Syakhsiyyah Islamiyah

Pembentukan Syakhsiyyah Islamiyah harus dilakukan pada semua jenjang pendidikan yang ada sesuai dengan proporsinya melalui berbagai pendekatan. Salah satu diantaranya adalah dengan menyampaikan tsaqofah Islam kepada para siswa/mahasiswa. Seperti tampak pada Tabel 2. Struktur dan performa komponen kurikulum, pada tingkat TK hingga SD materi Syakhsiyyah Islamiyah yang diberikan adalah Materi Dasar. Hal ini mengingat anak didik berada, pada jenjang usia menuju baligh, sehingga lebih banyak diberikan materi yang bersifat pengenalan menumbuhkan keimanan.

Barulah setelah mencapai usia baligh, yakni pada tingkat SMP, SMU dan PT, materi yang diberikan bersifat lanjutan (pembentukan, peningkatan dan pematangan). Hal ini dimaksudkan untuk memelihara dan sekaligus meningkatkan keimanan Berta keterikatan dengan syariat Islam. Indikatornya adalah bahwa anak didik dengan kesadaran yang dimilikinya telah berhasil melaksanakan seluruh kewajiban dan mampu menghindari segala tindak kemaksiyatan kepada Allah SWT.

\section{2) Tsaqofah Islam}

Tsaqofah Islam adalah ilmu-ilmu yang dikembangkan berdasar akidah Islam yang sekaligus menjadi sumber peradaban Islam. Muatan inti yang kedua ini diberikan pada seluruh jenjang pendidikan sesuai dengan proporsi yang telah ditetapkan. Materi yang diberikan adalah:

Pemberian materi Tsaqofah Islam sebagaimana digambarkan pada Tabel 2. Struktur dan Performa Komponen Kurikulum, diberikan secara bertingkat disesuaikan dengan tingkat kemampuan dan daya serap anak didik dari fingkat TK hingga PT. Sebagai contoh, target materi TififliYzu al-Qur'an untuk tingkat SD adalah 5 juz, SMP sebanyak 2,5 juz, SMU sebanyak 2,5 juz, sedang di PT diutamakan menghafal ayat-ayat yang terkait erat dengan bidang ilmu yang 
Model Pengembangan Karakter Melalui Sistem Pendidikan Terpadu...

ditekuninya. Sedangkan materi Ulumu al-Qur'an-nya barulah diberikan pada tingkat SMP sebagaimana materi Ulumu al-Hadist. Materi Ushul Fiqh mulai diberikan pada tingkat SMU.

\section{i. Dana, Sarana dan Prasarana}

Berdasarkan sirah Nabi SAW dan tarikh Daulah Khilafah sebagaimana disarikan oleh Al Baghdadi (1996: 12) dalam buku Sistem Pendidikan di Masa Khilafah Islam, negara memberikan jaminan pendidikan secara cuma-cuma (bebas biaya) dan kesempatan seluas-luasnya bagi seluruh warga untuk melanjutkan pendidikan ke jenjang Perguruan tinggi dengan fasilitas (sarana dan prasarana) sebaik mungkin. Kesejahteraan dan gaji para pendidik sangat diperhatikan dan merupakan beban yang harus dipikul negara serta diambil dari kas Baitul Maal. Sistem pendidikan bebas biaya tersebut didasarkan atas ijma sahabat yang memberi gaji kepada para pengajar dari baitul maal dengan jumlah tertentu.

\section{j. Lembaga Pendidikan Islam Unggulan}

Zaman pemerintahan Islam, sejak abad 4 Hijriah telah dibangun banyak sekolah Islam. Tetapi sebelum sekolah semodel itu dikembangkan, pendidikan ketika itu biasanya dilakukan di dalam masjid, majelis-majelis taklim dan tempat-tempat pendidikan keterampilan lainnya. Muhammad Athiyah Al Abrasi dalam buku dasar-dasar pendidikan Islam, memaparkan usaha-usaha para khalifah untuk membangun sekolah-sekolah itu.

Dalam perkembangannya, setiap khalifah berlomba-lomba membangun sekolah tinggi Islam dan berusaha melengkapinya dengan sarana dan prasarananya. Pada setiap sekolah tinggi itu dilengkapi dengan iwan (auditorium, gedung pertemuan), asrama penampungan mahasiswa, perumahan dosen dan ulama. Selain itu, sekolah tinggi tersebut juga dilengkapi dengan kamar mandi, dapur dan ruang makan, bahkan juga taman rekreasi.

Di antara sekolah-sekolah tinggi yang terpenting adalah Madrasah Nizhamiyah dan Madrasah Al Mustanshiriyah di Baghdad, Madrasah Al Nuriyah di Damaskus, serta Madrasah An-Nashiriyah di Kairo. Di antara madrasah-madrasah tersebut yang terballk adalah Madrasah Nizhamliyah. Sekolah ini akhirnya menjadi standar bagi daerah lain-nya di Irak, Khorasan (Iran) dan lainnya. 
Madrasah Al Mustanshiriyah di Baghdad didirikan oleh Khalifah AJ Mustanir pada abad ke 6 Hijriah. Sekolah ini memiliki sebuah auditorium dan perpustakaan yang dipenuhi berbagai, buku yang cukup untuk keperluan proses belajar mengajar. Selain itu, madrasah ini juga dilengkapi dengan pemandian, rumah sakit yang dokternya slap di tempat. Madrasah lain yang juga cukup terkenal adalah Madrasah Darin Hikmah di Kairo yang didirikan oleh Khalifah Al Hakim Biamrillah pada tahun 395 H. Madrasah ini adalah institut pendidikan yang dilengkapi dengan perpustakaan dan sarana serta prasarana pendidikan lainnya. Perpustakaannya dibuka untuk umum. Setiap orang boleh mendengarkan kuliah, ceramah ilmiah, simposium, aktifitas kesusastraan, dan telaah agama. Pada perpustakaan ini, seperti juga,-pada perpustakaan lainnya, dilengkapi dengan ruang-ruang studi dan ceramah serta ruang musik untuk refreshing bagi pembaca.

"Better education for better for better life" merupakan semangat bagi Lembaga Pendidikan Islam Terpadu Insantama Bogor untuk terus berkembang menjadi lebih baik. Lembaga Pendidikan Islam Terpadu Insantama Bogor berkomitmen untuk mempersembahkan metode pendidikan terbaik yang memadu-kan multi kecerdasan dalam koridor aqidah Islam yang lurus.

Lembaga Pendidikan Islam Terpadu Insantama Bogor senantiasa konsisten mewujudkan visi Sekolah Islam Insantama menjadi lembaga pendidikan Islam yang bermutu tinggi dan unggul di Indonesia. Sekolah Islam Insantama menyelenggara-kan pendidikan dasar dan menengah yang memadukan aspek pembentukan kepribadian Islam, penguasaan tsaqofah Islam dan sains teknologi dalam suasana budaya pendidikan yang religius serta didukung oleh peran serta orang tua dan masyarakat.

Berbekal pengalaman satu generasi, Sekolah Islam Insantama me-nyelenggarakan sekolah dasar dalam format full day school, dan sekolah menengah dalam format boarding school (asrama). Sekolah Islam Insantama hadir di berbagai kota di Indonesia, dan siap mengantarkannya menjadi generasi muslim yang tangguh. 


\section{Pengembangan Karakter Berdasar pada Landasan Budaya Sekolah}

Model pengembangan karakter akan selalu melekat pada bagaimana kinerja sekolah tersebut dalam mengembangkan budaya sekolah. Budaya sekolah sebagai aspek penting bagi pengembangan kepribadian siswa. Budaya sebagai produk manusia merupakan eksternalisasi yang memproduksi tatanan sosial yang terus-menerus mendasari pemahaman bagi setiap peran yang ada pada satuan pendidikan. Konsep eksternalisasi bahwa keberadaan manusia terusmenerus mengeksternalisasi-kan diri dalam aktivitas. Aktivitas yang telah menjadi kebiasaan, menghasilkan makna-makna yang sudah tertanam sebagai hal yang rutin. Pembiasaan memberikan arah dan spesialisasi kegiatan yang berlangsung sepanjang waktu dan membentuk suatu lembaga. Proses pelembagaan tindakan seharihari yang sudah dilakukan oleh masyarakat secara luas menjadi milik bersama. Demikian halnya dalam kehidupan di lingkungan sekolah terjadi proses pelembagaan tindakan sehari-hari yang dilakukan oleh semua unsur yang secara luas menjadi milik sekolah.

\section{Simpulan}

Berangkat dari paparan di atas, maka implemetasi pengembangan karakter adalah dengan mewujudkan lembaga pendidikan Islam unggulan secara terpadu dalam bentuk Taman Kanak-Kanak Islam Terpadu (TKIT), Sekolah Dasar Islam Terpadu (SDIT), Sekolah Menengah Islam Terpadu (SMPIT), Sekolah Menengah Umum Terpadu (SMUIT), dan Perguruan Tinggi Islam Terpadu.

Pengembangan Karakter dengan Pendidikan Islam Terpadu:

1. Keterpaduan Kurikulum Kepribadian Islam, Tsaqofah Islam dan Ilmu Kehidupan

2. Keterpaduan Pendidikan Sekolah, Keluarga dan Masyarakat Secara faktual, pendidikan melibatkan tiga unsur pelaksana, yakni keluarga, sekolah dan masyarakat. Kondisi faktual obyektif pendidikan saat ini, ketiga unsur pelaksana tersebut belum berjalan secara sinergis di samping masing-masing unsur tersebut juga belumlah berfungsi secara benar.

3. Keterpaduan Sekolah, Asrama/Pesantren dan Masjid 
Tiga poros sekolah, asrama/pesantren dan masjid yang berperan penting dalam pengembangan SDM tapi selama ini terpisah-pisah, harus dapat diharmonisasikan.

4. Dukungan Orang-Tua

Orang-tua sebaiknya memberi perhatian kepada anak-anak mereka dan menanamkan kepada mereka nilai dan tujuan pendidikan. Mereka juga berupaya mengetahui perkembangan anak mereka di sekolah.

5. Menyediakan waktu untuk anak

Selalu sediakan waktu yang cukup banyak bagi anak. Jika anak pulang sekolah, umumnya mereka cukup stres dengan beban pekerjaan rumah, ulangan, maupun problem lainnya.

6. Mengawasi kegiatan belajar di rumah Jangan melupakan menjadwalkan waktu setiap hari untuk memeriksa pekerjaan rumah anak. Kendalikan waktu menonton TV, internet dan bermain game dari anak-anak.

7. Mengajari tanggung jawab

Seorang anak dapat bertanggung jawab mengerjakan tugas mereka di sekolah jika telah mengajar mereka untuk mengerjakan tanggung jawab di rumah.

8. Disiplin

Jalankan disiplin dengan tegas namun dengan penuh kasih sayang.

9. Kesehatan

Jaga kesehatan anak agar prestasi belajarnya tidak terganggu Anak-anak yang kelelahan tidak dapat belajar dengan baik.

10. Menjadi teman terbaik

Meluangkan waktu untuk berbagi berbagai hal dengan mereka.

11. Mengembangkan Karakter melalui Budaya Pendidikan Budaya pendidikan sebagai aspek penting bagi peningkatan mutu pendidikan.

Terkait dengan kendala yang dihadapi, dalam membangun model pendidikan sebagaimana yang dikehendaki Islam tentu saja akan menghadapi kendala utama, yakni belum diterapkannya bangunan secara menyeluruh dalam kehidupan bermasyarakat dan bernegara. Model pendidikan atau sekolah unggulan sedemikian 
Model Pengembangan Karakter Melalui Sistem Pendidikan Terpadu...

hanya dapat diterapkan oleh Negara. Mengingat kendala di atas, maka harus ditempuh aksi individual atau kelompok kalangan muslim yang memang dibenarkan oleh hukum syara' selama memenuhi persyaratan lembaga pendidikan Islam, dari mulai asas kurikulumnya hingga operasional pendidikan keseharian. Inilah yang ditempuh melalui Pendidikan Islam Terpadu Insantama Bogor. 


\section{Daftar Pustaka}

Adimasana, Y.B. 2000. Revitalisasi pendidikan nilai di dalam sektor pendidikan formal dalam Transformasi pendidikan memasuki milenium ketiga. Ed A. Atmadi \& Y.Setyaningsih. Yogyakarta: Penerbitan Universitas Sanata Dharma.

Agustian, Ary Ginanjar. 2008. Pembentukan habit menerapkan nilai-nilai religius, sosial dan akademik. Proceeding. Seminar dan Lokakarya Nasional Rekonstruksi Pendidikan Karakter. Yogyakarta: UNY. 29 Juli 2008.

Albaghdadi, Abdurrahman. 1996. Sistem Pendidikan di Masa Khilafah Islam. Bangil: Al Izzah.

Alwisol. 2004. Psikologi Kepribadian.Malang: UMM Press.

Armstrong, Thomas. 2006. The best school. How human development research should inform educational practice. Virginia: Association for Supervision and Curriculum Development.

Basri, Husen Hasan. 2007. "Model Pengembangan Ekonomi Pondok pesantren Tiga Dimensi Pangkep, Sulawesi Selatan. Edukasi (Jurnal Penelitian Pendidikan Agama dan Keagamaan). Puslitbang Pendidikan Agama dan Keagamaan Badan Litbang dan Diklat Departemen Agama RI. Vol. 5, Nomor 4, oktoberDesember 2007, pp. 63-85.

Bertens, K. 1993. Etika. Jakarta: Gramedia.

Eko Prasetyo. 2004. Orang Miskin Dilarang Sekolah. Yogyakarta: Insits Press.

Hasbullah. 2005. Dasar-dasar Ilmu Pendidikan. Jakarta: Divisi Buku Perguruan Tinggi PT Raja Grafindo Persada.

Jess Feist \& Gregory J. Feist. 2008. Theories of Personality. New York: The McGraw Hill Companies, Inc., 1221 Aveneu of The Americas.

Karabel, Jerome and A.H. Halsey. 1977. Power and Ideology in Education (Edited and With an Introduction). New York: Oxford University Press.

Kuntoro, Sodiq A. 2008. "Sketsa Pendidikan Humanis Religius". 
Model Pengembangan Karakter Melalui Sistem Pendidikan Terpadu...

Paper disampaikan sebagai bahan diskusi dosen di Fakultas Ilmu Pendidikan (FIP). Yogyakarta: Universitas Negeri Yogyakarta.

McCauley, d. Cynthia, et.al. 1998. The center for creative leadership -handbook leadership development. San Francisco: Jeossey-Bass Publishers - Greensboro.

Miles, Matthew B. \& A. Michael Huberman. 1992. Analisis data kualitatif.Penerjemah-Tjetep Rohendi Rohidi. Jakarta: Penerbit Universitas Indonesia.

Muin M, Abd. 2007."Pondok Pesantren dan Pelayanan Masyarakat". Edukasi (Jurnal Penelitian Pendidikan Agama dan Keagamaan). Puslitbang Pendidikan Agama dan Keagamaan Badan Litbang dan Diklat Departemen Agama RI. Vol. 5, Nomor 4, oktober-Desember 2007, pp. 41-62.

Mujib, Abdul. 2005. Kepribadian Dalam Psikologi Islam. Jakarta: Raja Grafindo Persada.

Noeng Muhadjir.2003. Ilmu pendidikan dan perubahan sosial. Yogyakarta: Rake Sarasin.

. 2007. Metodologi Penelitian Kualitatif. Edisi V. Yogyakarta: Penerbit Rake Sarasin.

Sastrapratedja, M. 2009. Epistemologi Kultural. Hand Out Kuliah Epistemologi Kultural Pascasarjana Universitas Negeri Yogyakarta.

Siregar, Imran. 2007. "Supervisi Dalam Pembelajaran di Madrasah". Edukasi (Jurnal Penelitian Pendidikan Agama dan Keagamaan). Puslitbang Pendidikan Agama dan Keagamaan Badan Litbang dan Diklat Departemen Agama RI. Vol. 5, Nomor 4, OktoberDesember 2007, pp. 130-144.

Spraedley, James P. 1980. Participant Observation. New York: Holt, Rinehart and Wiston..

Undang-undang No. 20 Tahun 2003 tentang Sistem Pendidikan Nasional. Semarang: Media Wiyata. 
Agus Retnanto

halaman ini bukan sengaja dikosongkan 